\title{
Author Correction: Engaging with research impact assessment for an environmental science case study
}

\author{
Kirstie A. Fryirs (10, Gary J. Brierley (1) \& Thom Dixon (1)
}

Correction to: Nature Communications https://doi.org/10.1038/s41467-019-12020-z, published online 4 October 2019.

The original version of this Article has been corrected to include an extended Competing interests declaration: 'KF and GB are codevelopers of the River Styles Framework. River Styles foundation research has been supported through competitive grant schemes and university grants. Consultancy-based River Styles short courses taught by KF and GB are administered by Macquarie University. River Styles contract research is administered by Macquarie University and University of Auckland. River Styles as a trade mark expires in May 2020. TD declares no conflict of interest.' This replaced the original Competing interests declaration: 'K.F. and G.B. are codevelopers of the River Styles Framework. T.D. declares no competing interests.' This has been corrected in both the PDF and HTML versions of the Article.

Published online: 08 November 2019

(c) Open Access This article is licensed under a Creative Commons Attribution 4.0 International License, which permits use, sharing, adaptation, distribution and reproduction in any medium or format, as long as you give appropriate credit to the original author(s) and the source, provide a link to the Creative Commons license, and indicate if changes were made. The images or other third party material in this article are included in the article's Creative Commons license, unless indicated otherwise in a credit line to the material. If material is not included in the article's Creative Commons license and your intended use is not permitted by statutory regulation or exceeds the permitted use, you will need to obtain permission directly from the copyright holder. To view a copy of this license, visit http://creativecommons.org/licenses/by/4.0/.

(C) The Author(s) 2019 